\title{
Cell Suspension Culture of Plumbago europaea L. Towards Production of Plumbagin
}

\author{
Mina Beigmohamadi ${ }^{1}$, Ali Movafeghi ${ }^{1, *}$, Ali Sharafi ${ }^{2,{ }^{*}}$, Samineh Jafari ${ }^{3}$, Hossein Danafar ${ }^{4}$ \\ ${ }^{1}$ Faculty of Natural Science, University of Tabriz, Tabriz, Iran \\ ${ }^{2}$ Zanjan Applied Pharmacology Research Center, School of Pharmacy, Zanjan University of Medical Sciences, Zanjan, \\ Iran \\ ${ }^{3}$ Pharmacognosy Department, School of Pharmacy, Zanjan University of Medical Sciences, Zanjan, Iran \\ ${ }^{4}$ Zanjan Pharmaceutical Biotechnology Research Center, School of Pharmacy, Zanjan University of Medical Sciences, \\ Zanjan, Iran \\ * Corresponding author:
}

Ali Movafeghi, Faculty of Natural Science, University of Tabriz, Tabriz, Iran. E-mail: movafeghi@tabrizu.ac.ir

Ali Sharafi, Zanjan Applied Pharmacology Research Center, School of Pharmacy, Zanjan University of Medical Sciences, Zanjan, Iran. E-mail: alisharafi@zums.ac.ir

\begin{abstract}
Background: Plumbagin is as an important bioactive secondary metabolite found in the roots of Plumbago spp. The only one species, Plumbago europaea L., grows wild in Iran. The therapeutic use of plumbagin is limited due to its insufficient supply from the natural sources as the plants grow slowly and take several years to produce quality roots. Objectives: To develop an efficient protocol for the establishment of callus and cell suspension cultures of $P$. europaea and to evaluate production of plumbagin in callus and cell suspension cultures of $P$. europaea for the first time.

Material and Methods: Stems and leaves explants were cultured on agar solidified (7\% w/v) MS media, supplemented with different combination of 2, 4-D and Kin or 6-Benzylaminopurin (BA) for callus induction. The rapid growing calli were cultured in liquid Murashige and Skoog (MS) media in agitated condition for establishing cell suspension cultures of $P$. europaea. Moreover, the effects of light and dark conditions on the cell growth, cell viability and plumbagin production in cell suspension cultures of $P$. europaea were assessed.

Results: Friable calli were successfully induced using stem segments of $P$. europaea in semisolid MS medium supplemented with $1 \mathrm{mg} . \mathrm{L}^{-1}$ 2, 4-Dichlorophenoxy acetic acid (2, 4-D) and $0.5 \mathrm{mg} . \mathrm{L}^{-1}$ of kinetin (Kin). Optimal cell growth was obtained when the cells were grown in MS liquid media supplemented with $1 \mathrm{mg} . \mathrm{L}^{-1} 2$, 4-D and $0.5 \mathrm{mg} . \mathrm{L}^{-1}$ kinetin with an initial cell density of $\sim 3 \times 10^{5}$ cells per $\mathrm{ml}$ incubated in the dark at $25 \pm 1{ }^{\circ} \mathrm{C}$. Growth curve revealed that the maximum cell growth rate $\left(14.83 \times 10^{5}\right.$ cells per $\left.\mathrm{ml}\right)$ achieved on the day 18 and the highest plumbagin content $(0.9$ mg.g ${ }^{-1}$ Dry Cell Weight (DCW)) in the cells was obtained at the late exponential phase under dark condition which determined by High Performance Liquid Chromatography (HPLC) technique. Based on the obtained results, cell viability remained around $82.73 \%$ during the 18 days of cell culture in darkness. These suspension cultures showed continuous and stable production of plumbagin.

Conclusions: Our study suggests that cell suspension cultures of $P$. europaea represent an effective system for biosynthesis and production of plumbagin as a valuable bioactive compound.
\end{abstract}

Keywords: Cell Survival; Light; Plumbagin

\section{Background}

Plumbago L. (Plumbaginaceae) encompasses 12 species which are found mainly in Europe, the Mediterranean region, north Africa and southwest Asia. Among the species, only Plumbago europaea L. grows wild in Iran (2). The roots of $P$. europaea are reported to be the main source of plumbagin (5-hydroxy, 2-methyl, 1-4 naphthoquinone) as an important bioactive secondary metabolite $(3,4)$. Plumbagin possesses a wide range of pharmacological activities such as anticancer, antimicrobial, antimalarial, insecticidal, antiatherosclerosis, antioxidant, antifertility, filaricidal and cardiotonic agents (5-15). The quantity of 
plumbagin varies depending on growth and developmental stage of the plant as well as its locality and season conditions (16). Plumbagin has been shown to inhibit cell proliferation by inducing cells to undergo autophagic cell death $(17,18)$. According to Sandur et al (2006), Plumbagin down-regulates the expression of NF- $\mathrm{B}$ regulated anti apoptotic, proliferative and angiogenic gene products, which leads to apoptosis (19).

\section{Objective}

The biosynthesis of plumbagin and other naphthoquinones such as isoshinanolone and droserone takes place through the acetate-malonate pathway (20). The commercial use of wild grown plants has led to their rapid decline in the natural environment. On the other hand, the production of plumbagin by chemical synthesis is not commercially promising $(21,22)$. Fieser and Dunn (1936) successfully synthesized plumbagin entirely through chemical process but the synthetic approach of plumbagin production was not found to be commercially promising by Ichihara et al (1980) and Wurm et al (1986) (21-23). Thus, it is important to develop an efficient biotechnological system to enhance plumbagin production. Although biotechnological production of plumbagin using plant cell cultures of some Plumbago species has been studied $(2,24)$, the yields are required to be considerably enhanced for possible commercial exploitation. Light is an important factor, which affects not only growth and development of the plant but also the biosynthesis of primary and secondary metabolites $(25,26)$. Cell suspension culture is the preferred and reliable approach since it gives a homogenous fast growing material and is easy to scaleup. The large-scale cultivation system of cell and tissue culture using bioreactor is promising for the production of plant biomass and secondary metabolites. It has several advantages such as large mass propagation, controlled environment, consistency of the product and reducing the micropropagation cost (27). The present study introduces the capability of the cell cultures of $P$. europaea for in vitro biosynthesis of plumbagin and provides a framework for further investigations.

\section{Materials and Methods}

\subsection{Plant Materials}

The seeds and fresh samples of intact roots of Plumbago europaea were obtained from Research Institute of Forests and Rangelands, Tabriz, Iran. The surface disinfection of seeds was carried out under a laminar flow cabinet using sulfuric acid (98\%) for $5 \mathrm{~min}$, ethanol (70\%) for $45 \mathrm{~s}$ and sodium hypochlorite solution (2\%) for $10 \mathrm{~min}$. Then, they were rinsed in sterile distilled water and cultured on the solidified hormone-free MS media (28). The media were incubated in a phytotron at $25 \pm 1{ }^{\circ} \mathrm{C}$ under $16 / 8 \mathrm{~h}$ light/dark photoperiod (with cool white fluorescent light $\left.\left(40 \mu \mathrm{mol} \mathrm{m} \mathrm{m}^{-2} \mathrm{~s}^{-1}\right)\right)$. After three weeks of culture, in vitro grown plantlets were used as a source of explants (Fig. 2).

\subsection{Induction of Callus}

Stems and leaves segments $(1-1.5 \mathrm{~cm})$ were cultured on agar solidified ( $7 \% \mathrm{w} / \mathrm{v})$ MS media, supplemented with the different combination of 2, 4-D and Kin or 6Benzylaminopurin (BA) for callus induction (Table 1 and 2). The $\mathrm{pH}$ of the medium was adjusted to 5.8 before autoclaving. The media were autoclaved at 121 ${ }^{\circ} \mathrm{C}, \sim 105 \mathrm{kPa}$ for $20 \mathrm{~min}$. All cultures were incubated in dark at $25 \pm 1{ }^{\circ} \mathrm{C}$ and relative humidity maintained at $80 \%$. They were sub-cultured every 28 days. Thereafter, callus induction percentage, fresh weight of callus and texture of callus were evaluated using a completely randomized design method. Five replicates and five explants in each replicate were used. After 3 subcultures, the friable calli tissues were transferred to liquid MS media.

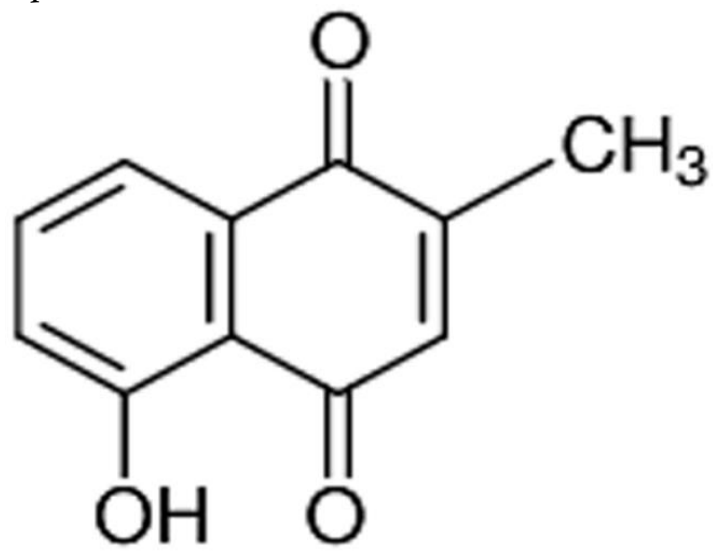

Figure 1. Structure of plumbagin (20)

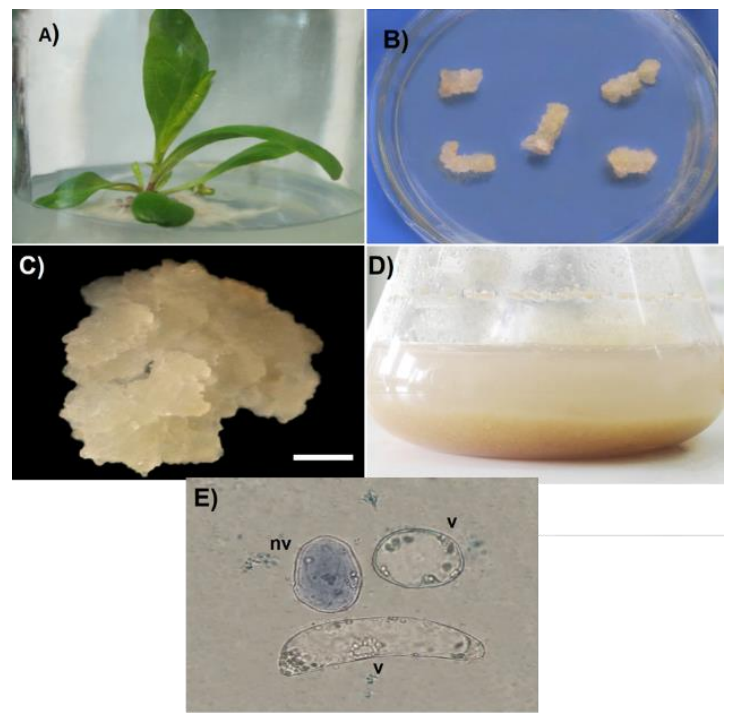

Figure 2. Establishment of the cell suspension cultures of Plumbago europaea. A) 3-weeks-old propagated plantlet; B and C. The callus tissues from stem explants on MS medium supplemented with 2, 4-D ( $\left.1 \mathrm{mg} . \mathrm{L}^{-1}\right)$ and Kin $\left.\left(0.5 \mathrm{mg} . \mathrm{L}^{-1}\right) ; \mathrm{D}\right)$ The suspension cell culture of $P$. europaea grown in flasks; E) Micrograph of the cell suspension culture showing viable cells $(\mathrm{v})$ and non-viable cells $(\mathrm{nv})(\times 40)$. 
Table 1. Effect of the exogenous plant growth regulators on the callus induction of internodal explants of Plumbago europeae after 28 day.

\begin{tabular}{|c|c|c|c|c|}
\hline Auxin, mg/l & Cytokinin, mg/l & Callus induction rate, $\%$ & Fresh weight, mg & Nature of callus \\
\hline 2,4-D & BA & & & \\
\hline \multirow[t]{4}{*}{$\mathbf{0}$} & 0 & $0^{d}$ & $0^{\mathrm{h}}$ & - \\
\hline & 0.5 & $0^{\mathrm{d}}$ & $0^{\mathrm{h}}$ & - \\
\hline & 1 & $0^{\mathrm{d}}$ & $0^{\mathrm{h}}$ & - \\
\hline & 2 & $0^{\mathrm{d}}$ & $0^{\mathrm{h}}$ & - \\
\hline \multirow[t]{4}{*}{0.5} & 0 & $88 \pm 10.95^{c}$ & $94 \pm 28.18^{g}$ & Little callus growth \\
\hline & 0.5 & $96 \pm 8.94^{\mathrm{ab}}$ & $125 \pm 22.20^{\mathrm{fg}}$ & friable \\
\hline & 1 & $100^{\mathrm{a}}$ & $146.8 \pm 23.23^{\text {ef }}$ & compact \\
\hline & 2 & $92 \pm 10.95^{b c}$ & $149.7 \pm 32.06^{\mathrm{ef}}$ & compact \\
\hline \multirow[t]{4}{*}{1} & 0 & $100^{\mathrm{a}}$ & $116.4 \pm 26.20^{\mathrm{fg}}$ & Little callus growth \\
\hline & 0.5 & $100^{\mathrm{a}}$ & $180.4 \pm 35.68^{\text {cde }}$ & friable \\
\hline & 1 & $100^{\mathrm{a}}$ & $187.3 \pm 19.03^{\mathrm{cd}}$ & friable \\
\hline & 2 & $100^{\mathrm{a}}$ & $184.3 \pm 31.69^{\mathrm{cd}}$ & compact \\
\hline \multirow[t]{5}{*}{2} & 0 & $88 \pm 17.88^{c}$ & $112 \pm 28.5^{\mathrm{g}}$ & Little callus growth \\
\hline & 0.5 & $100^{\mathrm{a}}$ & $147.2 \pm 26.29^{\mathrm{ef}}$ & friable \\
\hline & 1 & $100^{\mathrm{a}}$ & $164.1 \pm 23.02^{\mathrm{de}}$ & friable \\
\hline & 2 & $100^{\mathrm{a}}$ & $174.78 \pm 14.27^{\mathrm{de}}$ & compact \\
\hline & Kin & - & - & - \\
\hline \multirow[t]{3}{*}{$\mathbf{0}$} & 0.5 & $0^{d}$ & $0^{\mathrm{h}}$ & - \\
\hline & 1 & $0^{d}$ & $0^{\mathrm{h}}$ & - \\
\hline & 2 & $0^{\mathrm{d}}$ & $0^{\mathrm{h}}$ & - \\
\hline \multirow[t]{3}{*}{0.5} & 0.5 & $100^{\mathrm{a}}$ & $148.4 \pm 13.43^{\mathrm{ef}}$ & friable \\
\hline & 1 & $100^{\mathrm{a}}$ & $174.4 \pm 22.35^{\mathrm{de}}$ & friable \\
\hline & 2 & $100^{\mathrm{a}}$ & $164.6 \pm 37.94^{\mathrm{de}}$ & compact \\
\hline \multirow[t]{3}{*}{1} & 0.5 & $100^{\mathrm{a}}$ & $253.2 \pm 30.52^{\mathrm{a}}$ & friable \\
\hline & 1 & $100^{\mathrm{a}}$ & $212.4 \pm 19.57^{\mathrm{bc}}$ & friable \\
\hline & 2 & $100^{\mathrm{a}}$ & $226.18 \pm 22.56^{\mathrm{ab}}$ & compact \\
\hline \multirow[t]{3}{*}{2} & 0.5 & $100^{\mathrm{a}}$ & $173.24 \pm 46.23^{\mathrm{de}}$ & friable \\
\hline & 1 & $100^{\mathrm{a}}$ & $187.4 \pm 22.12^{\mathrm{cd}}$ & friable \\
\hline & 2 & $100^{\mathrm{a}}$ & $196.8 \pm 21.42^{\mathrm{bcd}}$ & compact \\
\hline
\end{tabular}

The data represent the mean \pm standard deviation of three independent experiments. The means followed by the same letters are not significantly different by Duncan's multiple range test $(\mathrm{P}<0.05)$.

Table 2. Effect of the exogenous plant growth regulators on callus induction of leaf explants of Plumbago europeae after 28 day.

\begin{tabular}{|c|c|c|c|c|}
\hline Auxin, mg/l & Cytokinin, mg/l & Callus induction rate, $\%$ & Fresh weight, mg & Nature of callus \\
\hline 2,4-D & $\mathrm{BA}$ & - & - & - \\
\hline \multirow[t]{4}{*}{ o } & 0 & $0^{\mathrm{e}}$ & $0^{f}$ & - \\
\hline & 0.5 & $0^{\mathrm{e}}$ & $0^{f}$ & - \\
\hline & 1 & $0^{\mathrm{e}}$ & $0^{f}$ & - \\
\hline & 2 & $0^{\mathrm{e}}$ & $0^{f}$ & - \\
\hline \multirow[t]{4}{*}{0.5} & 0 & $0^{\mathrm{e}}$ & $0^{f}$ & swelling \\
\hline & 0.5 & $92 \pm 10.95^{\mathrm{ab}}$ & $68.82 \pm 19.13^{\mathrm{e}}$ & Little callus growth \\
\hline & 1 & $92 \pm 10.95^{\mathrm{ab}}$ & $80.24 \pm 23.69^{e}$ & Little callus growth \\
\hline & 2 & $80 \pm 14.14^{\mathrm{cd}}$ & $76.02 \pm 20.79^{\mathrm{e}}$ & Little callus growth \\
\hline \multirow[t]{4}{*}{1} & 0 & $100^{\mathrm{a}}$ & $91.2 \pm 28.8^{\mathrm{e}}$ & Little callus growth \\
\hline & 0.5 & $100^{\mathrm{a}}$ & $130.8 \pm 18.78^{c}$ & friable \\
\hline & 1 & $100^{\mathrm{a}}$ & $148.66 \pm 38.5^{\mathrm{bc}}$ & friable \\
\hline & 2 & $84 \pm 16.73^{\text {bc }}$ & $129.4 \pm 18.74^{\mathrm{c}}$ & compact \\
\hline \multirow[t]{5}{*}{2} & 0 & $72 \pm 10.95^{\mathrm{d}}$ & $95.2 \pm 29.91 d^{e}$ & Little callus growth \\
\hline & 0.5 & $84 \pm 8.94^{\mathrm{bc}}$ & $123.9 \pm 22.046^{\mathrm{cd}}$ & friable \\
\hline & 1 & $100^{\mathrm{a}}$ & $136.1 \pm 23.01^{\mathrm{bc}}$ & friable \\
\hline & 2 & $96 \pm 8.94^{\mathrm{a}}$ & $143.5 \pm 14.13^{\mathrm{bc}}$ & compact \\
\hline & Kin & - & - & - \\
\hline \multirow[t]{3}{*}{$\mathbf{0}$} & 0.5 & $0^{\mathrm{e}}$ & $0^{\mathrm{f}}$ & - \\
\hline & 1 & $0^{\mathrm{e}}$ & $0^{f}$ & - \\
\hline & 2 & $0^{\mathrm{e}}$ & $0^{f}$ & - \\
\hline \multirow[t]{3}{*}{0.5} & 0.5 & $96 \pm 8.94^{\mathrm{a}}$ & $91 \pm 23.025^{\mathrm{e}}$ & Little callus growth \\
\hline & 1 & $100^{\mathrm{a}}$ & $99.04 \pm 22.54^{\mathrm{de}}$ & Little callus growth \\
\hline & 2 & $92 \pm 10.95^{\mathrm{ab}}$ & $94.8 \pm 27.20^{\mathrm{de}}$ & Little callus growth \\
\hline \multirow[t]{3}{*}{1} & 0.5 & $100^{\mathrm{a}}$ & $147.8 \pm 20.03^{\mathrm{bc}}$ & friable \\
\hline & 1 & $100^{\mathrm{a}}$ & $179.1 \pm 14.45^{\mathrm{a}}$ & friable \\
\hline & 2 & $100^{\mathrm{a}}$ & $165.78 \pm 47.05^{\mathrm{ab}}$ & compact \\
\hline \multirow[t]{3}{*}{2} & 0.5 & $92 \pm 17.88^{\mathrm{ab}}$ & $132.4 \pm 38.58^{c}$ & compact \\
\hline & 1 & $96 \pm 8.94^{\mathrm{a}}$ & $155 \pm 15.41^{\mathrm{abc}}$ & friable \\
\hline & 2 & $100^{\mathrm{a}}$ & $166.02 \pm 21.89^{\mathrm{ab}}$ & compact \\
\hline
\end{tabular}

The data represent the mean \pm standard deviation of three independent experiments. The means followed by the same letters are not significantly different by Duncan's multiple range test $(\mathrm{P}<0.05)$. 


\subsection{Establishment of Cell Suspension Cultures}

Cell suspension cultures were developed by transferring $3 \mathrm{~g}$ of friable calli derived from stem explants into $250 \mathrm{ml}$ flasks containing $100 \mathrm{ml}$ of fresh liquid MS medium supplemented with 2, 4-D (1 mg.. $\left.\mathrm{L}^{-1}\right)$, Kin $\left(0.5 \mathrm{mg} . \mathrm{L}^{-1}\right)$ and sucrose $\left(30\right.$ g. $\left.\mathrm{L}^{-1}\right)$. The $\mathrm{pH}$ of the media was adjusted to 5.8 before autoclaving. The suspension cultures were incubated at $25 \pm 1{ }^{\circ} \mathrm{C}$ under $16 \mathrm{~h}$ light: 8 $\mathrm{h}$ dark photoperiod of cool white fluorescent light $\left(40 \mu \mathrm{mol} \mathrm{m} \mathrm{m}^{-2} \mathrm{~s}^{-1}\right)$ or dark condition with continuous shaking at $110 \mathrm{rpm}$. Sub-culturing cell suspensions were conducted every 2 weeks by transferring an initial cell density of $3 \times 10^{5}$ cells per $\mathrm{ml}$ to the same liquid medium. To establish the growth kinetics and plumbagin production, individual flasks were sacrificed every 3 days over a 27 day period and used to determine the number of cells, cell viability and plumbagin content. Readings were carried out from three flasks for each parameter.

\subsection{Cell Number}

Cell density was estimated and monitored using a hemocytometer according to the method described by Oropeza et al. 2001 (29)

\subsection{Cell Viability}

The cell viability assay was determined by staining the cells using $0.25 \%$ Evan's blue by the method described by Rodrı'guez-Monroy and Galindo 1999 (30).

\subsection{Assay of Plumbagin}

A quantity of $1 \mathrm{~g}$ dried samples subjected to cold extraction using $100 \mathrm{ml}$ chloroform for $72 \mathrm{~h}$. The supernatant was collected by decantation into an amber colored bottle. The crude extracts were filtered by filter paper (Whatman, no. 1), evaporated by the rotary evaporator, dissolved separately in $5 \mathrm{ml}$ methanol and filtered through $0.45 \mu \mathrm{m}$ membranes before injection to the HPLC. A Breeze HPLC system from Waters Corporation (USA) was used at a wavelength of $270 \mathrm{~nm}$ with the outputs to record and analyze using a software (Breeze, USA). Plumbagin as standard was purchased from Sigma-Aldrich. An amount of $50 \mu \mathrm{L}$ of methanolic extract of sample was injected into $\mathrm{C} 8$ analytical column $(250 \mathrm{~mm} * 4.6 \mathrm{~mm}$, particle size $5 \mu \mathrm{m}$; Perfectsill, MZAnalysentechnik, Germany). The mobile phase was a mixture of methanol: water $(80: 20)$ and run at the isocratic condition with a flow rate of $0.9 \mathrm{ml} \mathrm{min}^{-1}$. The chromatographic peak of plumbagin was confirmed by comparing its retention time with that of the standard (31). Quantitative estimation of plumbagin was carried out based on the peak area of specific concentrations of the sample and the standard. The area under the peaks of plumbagin was integrated and converted to concentration using its calibration curve.

\subsection{Statistical Analysis}

Statistical analysis was performed using one-way analysis of variance (ANOVA) followed by Duncan's multiple range test for inter-group comparisons, using the SPSS 16.0 (Statistical Program for Social Sciences) program. The level of significance was set at $\mathrm{P}<0.05$.

\section{Results}

\subsection{Callus Induction}

Table 1 and Table 2 show the effects of different combinations of plant growth regulators tested for callus induction, callus fresh weight and nature of callus in the stem and leaf explant. Callus tissues were effectively induced in leaf and shoot explant by all combinations of 2, 4-D and Kin or BA (Table 1 and Table 2) whereas no callus was generated on growth regulator free MS media. Therefore, it can be concluded that callus induction from leaf and stem explants of $P$. europeae is mainly influenced by the exogenous plant growth regulators. In stem segments, callus induction was mostly appeared on days 6-9 of culture, whereas in the leaf explants, callus induction occurred slower and after 11-13 days. In the present study, the cytokinin (BA or Kin) treatment without auxin (2, 4-D) did not induce callus, whereas the exclusive presence of 2, 4-D in the medium and the absence of cytokinins (BA or Kin), was resulted in higher callus weight (Table1 and Table 2). However, the combinations of auxins (2, 4-D) and cytokinins (BA or Kin) were found to produce more callus tissues than the media containing auxin or cytokinin alone.

Using stem explants, the highest callus fresh weight (253.20 $\mathrm{mg} \mathrm{FW}$ ) and the best callus texture were obtained in MS medium containing $1 \mathrm{mg} . \mathrm{L}^{-1} 2$, 4-D and $0.5 \mathrm{mg} . \mathrm{L}^{-1} \mathrm{Kin}$ on the $28^{\text {th }}$ day and were yellowish-white in color and more friable in nature (Fig. 2). After 4 weeks, the calli were sub-cultured on the same medium, to achieve more friable callus prior to initiation of cell suspension cultures. In comparison, MS medium supplemented with $1 \mathrm{mg} . \mathrm{L}^{-1} 2$, 4-D and $1 \mathrm{mg} . \mathrm{L}^{-1} \mathrm{Kin}$ was suitable for callus development from leaf explants (179.10 mg FW) (Table 2). In the callus culture (stemderived ) grown on MS medium supplemented with 1 mg. $\mathrm{L}^{-1} 2$, 4-D and $0.5 \mathrm{mg} . \mathrm{L}^{-1}$ Kin after 3 sub-cultures, plumbagin content was $0.084 \mathrm{mg} \cdot \mathrm{g}^{-1} \mathrm{DW}$ (Fig. 4d). We found also that the intact roots of $P$. europaea in natural environment contain $1.78 \mathrm{mg} \cdot \mathrm{g}^{-1} \mathrm{DW}$ of plumbagin (Fig. 4b). Stem explants exhibited the higher frequency of callus formation and the higher fresh weight compared to leaf explants. Hence, stem explants were used for further experiments.

\subsection{Suspension Cultures}

Suspension cultures were initiated by transferring fresh friable stem-derived calli into liquid MS medium supplemented with $1 \mathrm{mg} . \mathrm{L}^{-1} 2$, 4-D and $0.5 \mathrm{mg} . \mathrm{L}^{-1} \mathrm{Kin}$. The suspension cultures were established by regular sub-culturing and became completely uniform after 6 weeks. Cell growth was measured by recording the cell number every 3 days. In this study, we compared the influence of lighting conditions (total darkness versus $16 \mathrm{~h}$ light: $8 \mathrm{~h}$ dark photoperiod) on the cell growth, cell 
viability and plumbagin production of cell suspensions of $P$. europaea. Fig. 3 shows the effect of light and dark conditions (total darkness versus $16 \mathrm{~h}$ light: $8 \mathrm{~h}$ dark photoperiod) on the growth of cell cultures and plumbagin accumulation.

In a suspension culture of $P$. europaea, an S-shaped growth-curve was generally observed in both lighting conditions (Figs. 3A and 3B). Cell suspensions were characterized by an initial lag phase around day 6 (a period of cellular adaptation to the new medium). The initial lag phase was followed by exponential growth phase from $6^{\text {th }}$ to $18^{\text {th }}$ day of culture. The cultures showed about 5 -fold increase in cell density $\left(14.83 \times 10^{5}\right.$ cells per $\mathrm{ml}$ ) and 4-fold increase in cell density $\left(11.97 \times 10^{5}\right.$ cells per $\left.\mathrm{ml}\right)$ on the $18^{\text {th }}$ day under dark and light conditions, respectively. The stationary phase followed by a gradual reduction in cell density due to senescence of the cells and deficiency of the nutrient in the medium (Fig. 3). Based on the obtained growth curve, the day of the sub-culture was optimized between days 15 and 18 of incubation, which was the end of the exponential growth phase according to the suggestion of Stafford and Warren (32).

Our results indicated that the optimal cell growth was obtained when the cells were grown in MS media supplemented with $1 \mathrm{mg} . \mathrm{L}^{-1} 2$, 4-D and $0.5 \mathrm{mg} . \mathrm{L}^{-1}$ of Kin with an initial cell density of $\sim 3 \times 10^{5}$ cells per $\mathrm{ml}$ in dark. The results showed that cell growth requires a certain initial density of cells. Poor results obtained at low $\left(1 \times 10^{5}\right.$ cells per $\left.\mathrm{ml}\right)$ and high $\left(6 \times 10^{5}\right.$ cells per $\left.\mathrm{ml}\right)$ initial cell density (data not shown). The present study confirmed the concept that the stimulatory influence of initial inoculums affects the cell growth kinetics in plant cell cultures (33).

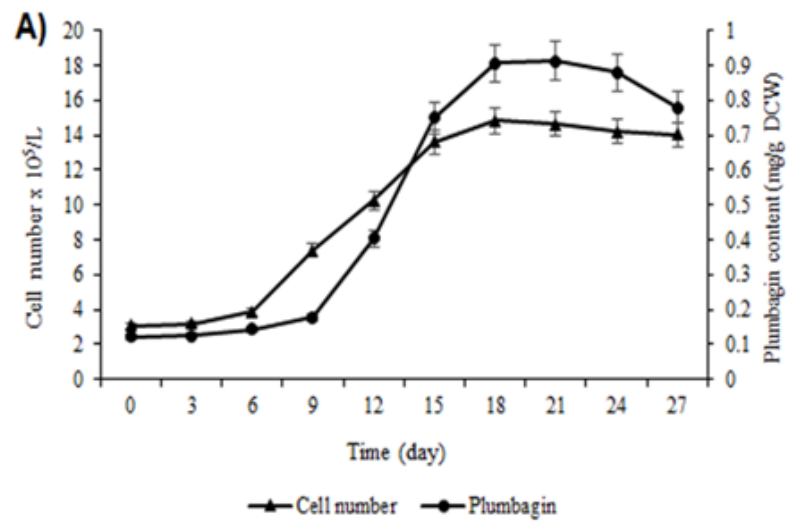

B)

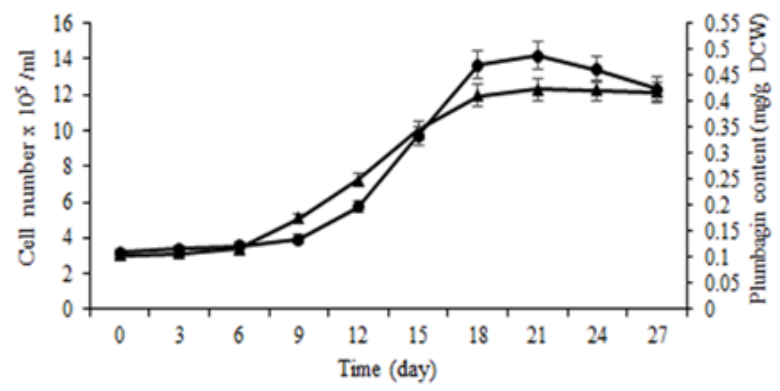

$\leftarrow$ Cell number $\rightarrow$ Plumbagin

Figure. 3. The growth curve and the plumbagin content of the cultured cells of $P$. europaea in A) dark and B) photoperiod conditions during a period of 27 days.
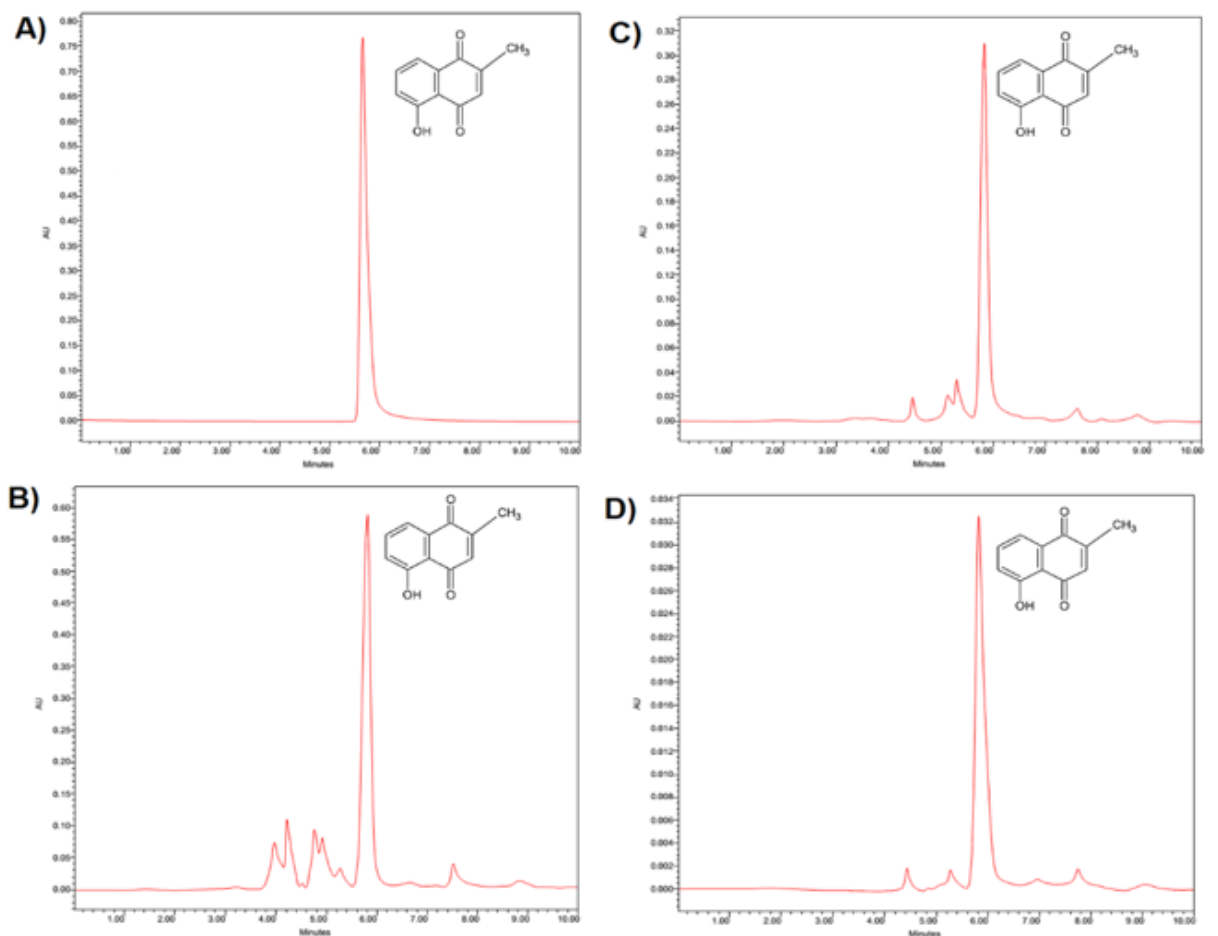

Figure 4. HPLC spectra of pure plumbagin as standard (A) and extracted plumbagin from intact root of Plumbago europaea (B) extracted plumbagin from the cell suspension culture of P. europaea (2, 4-D $1 \mathrm{mg} / \mathrm{L}+$ Kin $0.5 \mathrm{mg} / \mathrm{L})(\mathrm{C})$ and extracted plumbagin from the callus culture of $P$.europaea (2, 4-D $1 \mathrm{mg} / \mathrm{L}+\operatorname{Kin} 0.5 \mathrm{mg} / \mathrm{L})(\mathrm{D})$. 
Microscopic observation of suspension cultures showed that the cells were round or oval shape (Fig. 2). Based on the Evans blue staining method, the cell viability was calculated under a light microscope (staining the dead cells) (Fig. 2). Cell viability of the cultures under regular photoperiod condition did not show any significant difference with those in darkness. The survival rate at the $18^{\text {th }}$ day for cells under light was $80.8 \%$, while under the dark condition it was about $82.73 \%$ (Fig. 5). The viability of cells decreased slightly until the $18^{\text {th }}$ day $(82.73 \%)$ and consequently decreased by $56.4 \%$ on the $27^{\text {th }}$ day in the dark. (Fig. 5).

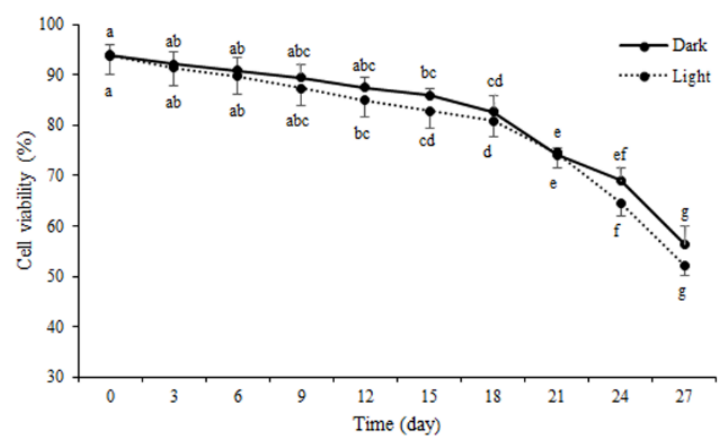

Figure 5. Cell viability of the suspension culture of P. europaea under light and dark conditions during the culture time.

Dynamics of plumbagin accumulation in $P$. europaea suspension culture, during its cultivation cycle presented in Figure 3. Our data revealed that the dynamics of plumbagin production in $P$. europaea suspension culture was growth-associated during the growth cycle (Fig. 3). Intriguingly, plumbagin accumulation was high in the late logarithmic phase (Fig. 3). The maximum contents of plumbagin in cell suspension cultures incubated in dark $\left(0.9 \mathrm{mg} \mathrm{g}^{-1}\right.$ DCW $)$ and in photoperiod condition (0.52 mg. $\mathrm{g}^{-1}$ DCW) were observed when the cultures moved from the exponential into the stationary phase (at the 21st day of cultivation cycle).

\section{Discussion}

Callus initiation is a primary and necessary step in a number of tissue culture processes such as establishment of cell suspension cultures, regeneration of plants and indirect somatic embryogenesis (34-36). In the current study, callus culture was used for establishment of cell suspension cultures of $P$. europaea for the first time. To obtain a good suspension culture, it is critical to initiate the suspension cultures from a friable callus source $(37,38)$. Using leaf and stem explants callogenesis was successfully achieved in both types of the explants. The callus obtained from stem explants in MS medium containing 2, 4-D (1 mg..-1) and kinetin $\left(0.5 \mathrm{mg} . \mathrm{L}^{-1}\right)$ exhibited highest fresh weight compared to leaf explants and produced soft and friable. However, stem explants were more suitable for callus induction than leaf explants. Similar findings were reported for Corydalis saxicola (39) and Orthosiphon stamineus (40). Seeni and Komaraiah (2002) have used stem derived callus for the establishment of cell suspension cultures of $P$. indica.

In the present study, MS basal liquid medium supplemented with $3 \%$ sucrose and $1 \mathrm{mg} . \mathrm{L}^{-1}(2,4-\mathrm{D})$ and $0.5 \mathrm{mg} . \mathrm{L}^{-1} \mathrm{BA}$, was found producing higher biomass accumulation of $(253.20 \mathrm{mg} \mathrm{FW})$ on day 28 (Table 2). Our results exhibited that callus induction from leaf and stem explants of $P$. europeae is mainly influenced by the exogenous plant growth regulators. However, the combinations of auxins and cytokinins were found to produce more callus tissues than the media containing auxin or cytokinin alone. The positive effect of plant growth regulators on callus induction has been previously reported for several plant species $(35,41)$. In fact, auxins play a more important role in callus induction and cytokinins (BA or Kin) facilitate their effects $(39,42,43)$. Synergetic effects of plant growth regulators play a critical role in callus induction and cell differentiation (44). Auxins and cytokinins are necessary for cell division at the G1-S and G2-M transitions in cultured plant cells and in planta (45). Auxins stimulate the acidification of the cell wall resulting in increasing extensibility and also induce the transcription of specific mRNAs which code for proteins associated with cellular growth. In comparison, cytokinins act directly on the cell cycle by regulating the synthesis of proteins involved in the formation and operation of the mitotic spindle (45-47).

Our results indicate that the combination of 2, 4-D and Kin was more effective than 2, 4-D and BA to induce adequate calli from stem explants of $P$. europaea. This finding is in fair agreement with previous reports in callus induction of $P$. indicia showing the noteworthy effect of 2, 4-D and Kin $(24,48)$. In general, our findings indicated that the type and combination of plant growth regulators and explant types had significant effects on callus induction of $P$. europaea. These differences can be attributed to variation in endogenous hormone content in the explant or different sensitivities of the tissue to the plant growth regulators (49).

Cell cultures of $P$. europeaa showed a sigmoid growth pattern, which started with the lag phase, followed by the exponential phase and ended with the stationary phase. Hence, subcultures have to be carried out before the cultures enter the stationary phase in order to maintain the cell lines for prolonged durations and in a healthy condition. Similar results were previously reported in the establishment of suspension cultures of $P$. indica $(2,24)$. It seems that consumption of the nutrients and other restricting factors in the medium has an influence not only on the growth and cell viability but also on the synthesis of this important secondary metabolite during the stationary phase. It was previously revealed that in around 50\% cell viability, the establishment of suspension cultures will fail (50). Our 
results showed that the cell suspension cultures of $P$. europaea have successfully established.

Light is an important physical factor which affects not only growth and development of the plant but also biosynthesis metabolites in many plant cell cultures $(25$, 26). Also, the effects of light and dark on cell growth, plumbagin formation and cell viability were examined by cell suspension culture of P. europeaa in this study. Cell cultures grown in dark exhibited higher cell growth $\left(14.83 \times 10^{5}\right.$ cells per $\left.\mathrm{ml}\right)$ at the end of exponential phase compared to cell cultures under the light condition $\left(11.97 \times 10^{5}\right.$ cells per $\left.\mathrm{ml}\right)$ (Figs. $3 \mathrm{~A}$ and $3 \mathrm{~B}$ ). The plumbagin content in cell suspension cultures incubated under dark condition was 1.7 -fold higher than in cell suspension cultures grown under photoperiod condition. Bias et al. stated that the cell cultures of Hypericum perforatum incubated in darkness showed an increase in biomass yield and hypericin accumulation (51). Our findings confirm the previous reports showing that light has an inhibitory effect on the accumulation of some secondary metabolites such as shikonin and nicotine in the hairy root and cell suspension cultures of Lithospermum erythrorhizon (52, 53) and phenolic compounds in cell suspension cultures of Thevetia peruviana (54).

The results revealed that the dynamics of plumbagin production in $P$. europaea suspension culture was growth-associated during the growth cycle in both lighting conditions (Fig. 3). Our findings are in agree with the previous reports of Komaraiah, Ramakrishna (2) and Satheeshkumar, seeni (24), who shown that increase in the concentration of plumbagin can be parallel to the growth of cells in cell suspension cultures. Production of plumbagin in cell suspension cultures has been investigated earlier in Dionaea muscipula, Drosera species (55) and Drosophyllum lusitanicum (56). Plumbagin was also isolated from cell suspension culture of $P$. rosea (2). Satheeshkumar and seeni have reported $0.028 \mathrm{mg} \cdot \mathrm{g}^{-1} \mathrm{DW}$ and $0.05 \mathrm{mg} \cdot \mathrm{g}^{-1} \mathrm{DW}$ plumbagin in cell suspension cultures and callus cultures of $P$. indica (24). Heble et al. (1974) reported that plumbagin concentration was $0.0001-0.0003 \%$ FW callus culture in P. zeylanica. The amount of plumbagin in root cultures of $P$. rosea was $0.016 \pm 0.0030 \%$ DW (57). Higher plumbagin production $\left(4.3 \mathrm{mg} \cdot \mathrm{g}^{-1}\right)$ was reported in suspension cultures of $P$. indica (2). The contradictory results reported by several authors concerning the accumulation of plumbagin in Plumbago cell and callus cultures may be explained by the variation in nutrient media and culture conditions used for initiation of Plumbago cell suspension, difference in genotype of explants and the unstable level of these compounds during culture.

The plumbagin content in intact roots of $P$. europaea in the natural environment was $1.78 \mathrm{mg} \cdot \mathrm{g}^{-1} \mathrm{DW}$. Plumbagin production in this tissue was 2 - and 22 -folds higher than in cell cultures grown in the dark $\left(0.9 \mathrm{mg} . \mathrm{g}^{-}\right.$

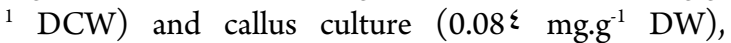

respectively. Our results are in corroboration with Nahahlka et al. (1996) who has also reported more amounts of plumbagin in Drosophyllum suspension cultures than in callus. Although the concentration of plumbagin in callus and suspension cultures was less than the intact roots, the growing time of suspension culture is very shorter in comparison to field growing plants. Furthermore, plant cell suspension culture is the most favorite technique, since it gives a homogenous fast growing material, represents simple methods and is easy to scale-up. Using this technique, the dependence on intact plants and the mass destruction of natural resources will be reduced. However, further investigations are needed to improve plumbagin production under in vitro condition.

\section{Conclusions}

In the present study, we established a reliable and effective callus and cell suspension cultures of $P$. europaea. Further, the obtained data revealed that plumbagin could produce through callus and cell suspension cultures of $P$. europaea. The friable callus tissues were produced by culturing the stem explants on MS medium supplemented with $1 \mathrm{mg} . \mathrm{L}^{-1} 2,4-\mathrm{D}$ and 0.5 mg. $L^{-1}$ Kin. The ability of cell suspension cultures to produce plumbagin was examined during their growth cycles. Cell growth and plumbagin content were higher when cultures were incubated in the dark than those cultures under a photoperiod mode. This study showed that suspension cultures of $P$. europaea as a green factory is a promising technology for the synthesis of the valuable compound plumbagin.

\section{Conflict of Interest}

There is no conflict of interest with this study.

\section{References}

1. Ghahreman A. Flore de l'Iran. Tehran: University of Tehran; 1993.

2. Komaraiah P, Ramakrishna SV, Reddanna P, Kavi Kishor PB. Enhanced production of plumbagin in immobilized cells of Plumbago rosea by elicitation and in situ adsorption. J Biotechnol. 2003;101(2):181-187. doi: 10.1023/A:1010545630018. pmid: 12568747

3. Navaei MN, Mirza M, Dini M. Chemical composition of the essential oil ofPlumbago europaea L. roots from Iran. Flavour Fragr J. 2005;20(2):213-214. doi: 10.1002/ffj. 1384

4. Kitanov GM, Pashankov PP. Quantitative investigation on the dynamics of plumbagin in Plumbago europaea L. roots and herb by HPLC. Pharmazie. 1994;49(6):3560.

5. Nair S, Nair RR, Srinivas P, Srinivas G, Pillai MR. Radiosensitizing effects of plumbagin in cervical cancer cells is through modulation of apoptotic pathway. Mol Carcinog. 2008;47(1):22-33. doi: 10.1002/mc.20359 pmid: 17562542

6. Ding Y, Chen ZJ, Liu S, Che D, Vetter M, Chang CH. Inhibition of Nox-4 activity by plumbagin, a plant- 
derived bioactive naphthoquinone. J Pharm Pharmacol. 2005;57(1):111-116. doi: 10.1211/0022357055119 pmid: 15638999

7. Tan M, Liu Y, Luo X, Chen Z, Liang H. Antioxidant Activities of Plumbagin and Its $\mathrm{Cu}$ (II) Complex. Bioinorg Chem Appl. 2011;2011:898726. doi: 10.1155/2011/898726 pmid: 22046145

8. Kubo I, Uchida M, Klocke JA. An insect ecdysis inhibitor from the African medicinal plant, Plumbago capensis (Plumbaginaceae); a naturally occurring chitin synthetase inhibitor. Agricult Biol Chem. 1983;47(4):911-913. doi: 10.1271/bbb1961.47.911.

9. Mathew N, Paily KP, Abidha, Vanamail P, Kalyanasundaram M, Balaraman K. Macrofilaricidal activity of the plantPlumbago indica/rosea in vitro. Drug Dev Res 2002;56(1):33-39. doi: 10.1002/ddr.10056

10. Itoigawa M, Takeya K, Furukawa H. Cardiotonic action of plumbagin on guinea-pig papillary muscle. Planta Med. 1991;57(4):317-319. doi: 10.1055/s-2006960106 pmid: 1775570

11. Likhitwitayawuid K, Kaewamatawong R, Ruangrungsi $\mathrm{N}$, Krungkrai J. Antimalarial naphthoquinones from Nepenthes thorelii. Planta Med. 1998;64(3):237-241. doi: $10.1055 / \mathrm{s}-2006-957417$ pmid: 9581522

12. Kuo PL, Hsu YL, Cho CY. Plumbagin induces G2-M arrest and autophagy by inhibiting the $\mathrm{AKT} /$ mammalian target of rapamycin pathway in breast cancer cells. Mol Cancer Ther. 2006;5(12):32093221. doi: 10.1158/1535-7163.MCT-06-0478 pmid: 17172425

13. Thasni KA, Rakesh S, Rojini G, Ratheeshkumar T, Srinivas G, Priya S. Estrogen-dependent cell signaling and apoptosis in BRCA1-blocked BG1 ovarian cancer cells in response to plumbagin and other chemotherapeutic agents. Ann Oncol. 2008;19(4):696705. doi: $10.1093 /$ annonc/mdm557 pmid: 18187487

14. Nair SV, Baranwal G, Chatterjee M, Sachu A, Vasudevan AK, Bose C, et al. Antimicrobial activity of plumbagin, a naturally occurring naphthoquinone from Plumbago rosea, against Staphylococcus aureus and Candida albicans. Int $J$ Med Microbiol. 2016;306(4):237-248. doi: 10.1016/j.ijmm.2016.05. 004 pmid: 27212459

15. Sandeep G, Dheeraj A, Sharma NK, Jhade D, Bharti A. Effect of plumbagin free alcohol extract of Plumbago zeylanica Linn. root on reproductive system of female Wistar rats. Asian Pac J Trop Med. 2011;4(12):978-984. doi: $\quad 10.1016 /$ S1995-7645(11)60230-7 pmid: 22118035

16. Kurian A, Sankar MA. Medicinal plants: New India Publishing; 2007.

17. Cao YY, Yu J, Liu TT, Yang KX, Yang LY, Chen Q et al. Plumbagin inhibits the proliferation and survival of esophageal cancer cells by blocking STAT3-PLK1-AKT signaling. Cell Death Dis. 2018;9(2):17. doi: 10.1038/s41419-017-0068-6 pmid: 29339720

18. Li YC, He SM, He ZX, Li M, Yang Y, Pang JX, et al. Plumbagin induces apoptotic and autophagic cell death through inhibition of the PI3K/Akt/mTOR pathway in human non-small cell lung cancer cells. Cancer Lett. 2014;344(2):239-259. doi: 10.1016/j.canlet.2013.11 .001 pmid: 24280585
19. Sandur SK, Ichikawa H, Sethi G, Ahn KS, Aggarwal BB. Plumbagin (5-Hydroxy-2-methyl-1,4naphthoquinone) suppresses NF- $\mathrm{kB}$ activation and NF$\kappa \mathrm{B}$-regulated gene products through modulation of $\mathrm{p} 65$ and I $\kappa B$ a kinase activation, leading to potentiation of apoptosis induced by cytokine and chemotherapeutic agents. J Biol Chem. 2006;281:17023-17033.

20. Durand R, Zenk MH. Biosynthesis of plumbagin (5hydroxy-2-methyl-1,4-naphthoquinone) via the acetate pathway in higher plants. Tetrahedron Lett. 1971;12(32):3009-3012. doi: 10.1016/s00404039(01)97077-7

21. Wurm G, Gurka H-J. Untersuchungen an 1,4Naphthochinonen, 13. Mitt. Neue Synthesen für Plumbagin und Isoplumbagin. Arch Pharm. 1986;319(2):190-191. 10.1002/ardp.19863190219

22. Ichihara A, Ubukata M, Sakamura S. Synthesis of plumbagin by the retro-Diels-Alder reaction. Agricult Biol Chem. 1980;44(1):211-213. doi: 10.1271/bbb1961.44.211.

23. Fieser LF, Dunn JT. Synthesis of plumbagin. J Am Chem Soc. 1936;58(4):572-575.

24. Satheeshkumar K, Seeni S. Production of plumbagin (5hydroxy 2-methyl 1: 4 naphthoquinone) in callus and cell suspension cultures of Plumbago indica Linn. Indian J Biotechnol. 2002;1:305-308.

25. Vázquez-Flotaand FA, Luca VD. Jasmonate modulates development- and light-regulated alkaloid biosynthesis in catharanthus roseus fn $1 \mathrm{fn} 1$ Dedicated to Dr. Neil Towers on the occasion of his seventy-fifth birthday. Phytochemistry. 1998;49(2):395-402. doi: 10.1016/s0031-9422(98)00176-9

26. Halliday KJ, Fankhauser C. Phytochrome-hormonal signalling networks. New Phytol. 2003;157(3):449-463. doi: 10.1046/j.1469-8137.2003.00689.x

27. Paek KY, Chakrabarty D, Hahn EJ. Application of bioreactor systems for large scale production of horticultural and medicinal plants. Plant Cell Tissue Organ Cult. 2005;81(3):287-300. doi: $10.1007 /$ s11240-004-6648-z

28. Murashige T, Skoog F. A revised medium for rapid growth and bio assays with tobacco tissue cultures. Physiol Plant. 1962;15(3):473-497. doi: 10.1111/j.1399-3054.1962.tb08052.x.

29. Oropeza M, Marcano AK, De García E. Proteins related with embryogenic potential in callus and cell suspensions of sugarcane (Saccharum sp.). In Vitro Cell Dev Biol Plant. 2001;37(2):211-216. doi: 10.1007/11627-001-0037-7

30. Rodríguez-Monroy M, Galindo E. Broth rheology, growth and metabolite production of Beta vulgaris suspension culture: a comparative study between cultures grown in shake flasks and in a stirred tank. Enzyme Microbial Technol. 1999;24(10):687-693. doi: 10.1016/s0141-0229(99)00002-2

31. Muhammad HM, Saour KY, Naqishbandi AM. Quantitative and qualitative analysis of Plumbagin in the leaf and root of Plumbago europaea growing naturally in Kurdistan by HPLC. Iraqi J Pharm Sci. 2017;18(Suppl.):54-59.

32. Stafford A, Warren G. Plant cell and tissue culture. Buckingham, UK: Open University Press; 1991. 
33. Mukherjee S, Ghosh B, Jha S. Establishment of forskolin yielding transformed cell suspension cultures of Coleus forskohlii as controlled by different factors. J Biotechnol. 2000;76(1):73-81. doi: 10.1016/s01681656(99)00181-9 pmid: 10784298

34. Kumar S, Kanwar JK. Plant regeneration from cell suspensions in Gerbera jamesonii Bolus. J Fruit Ornam Plant Res. 2007;15(2):157. doi: 10.1.1.558.3702.

35. Mathur S, Shekhawat GS. Establishment and characterization of Stevia rebaudiana (Bertoni) cell suspension culture: an in vitro approach for production of stevioside. Acta Physiol Plant. 2012;35(3):931-939. doi: 10.1007/s11738-012-1136-2

36. Ipekci Z, Gozukirmizi N. Indirect somatic embryogenesis and plant regeneration from leaf and internode explants of Paulownia elongata. Plant Cell Tissue Organ Cult. 2004;79(3):341-345. doi: 10.1007/s11240-003-4632-7.

37. Mohamad Zuldin NN, Said IM, Mohd Noor N, Zainal $Z$, Jin Kiat C, Ismail I. Induction and analysis of the alkaloid mitragynine content of a Mitragyna speciosa suspension culture system upon elicitation and precursor feeding. ScientificWorldJournal. 2013;2013:209434. doi: 10.1155/2013/209434 pmid: 24065873

38. Negahdary M, Omidi S, Eghbali-Zarch A, Mousavi SA, Mohseni G. Plant synthesis of silver nanoparticles using Matricaria chamomilla plant and evaluation of its antibacterial and antifungal effects. Biomed Res. 2015;26:794-799.

39. Cheng H, Yu LJ, Hu QY, Chen SC, Sun YP. Establishment of callus and cell suspension cultures of Corydalis saxicola Bunting, a rare medicinal plant. $Z$ Naturforsch C. 2006;61(3-4):251-256. doi: 10.1515/znc-2006-3-416 pmid: 16729585

40. Wai-Leng L, Lai-Keng C. Establishment of Orthosiphon stamineus cell suspension culture for cell growth. Plant Cell Tissue Organ Cult. 2004;78(2):101-106. doi: 10.1023/B:TICU.0000022533.83592.37

41. Khanpour-Ardestani N, Sharifi M, Behmanesh M. Establishment of callus and cell suspension culture of Scrophularia striata Boiss.: an in vitro approach for acteoside production. Cytotechnology. 2015;67(3):475485. doi: $10.1007 / \mathrm{s} 10616-014-9705-4$ pmid: 25344876

42. Rostampour S, Sohi H, Dehestani A. In vitro regeneration of Persian poppy (Papaver bracteatum). Biologia. 2010;65(4):647-652. doi: 10.2478/s11756010-0079-6

43. Mirzaee H, Sharafi A, Hashemi Sohi H. In vitro regeneration and transient expression of recombinant sesquiterpene cyclase (SQC) in Artemisia annua $L$. South Afr J Botan. 2016;104:225-231. doi: 10.1016/j.sajb.2015.10.005

44. Shoja AM, Hassanpouraghdam Mb, Khosrowshahli M, Movafeghi A. Callogenesis capability and calli somaclonal variation of costmary (Tanacetum balsamita L.). Romanian Biotechnol Lett. 2010;15(2):5120-5124.

45. Stals H, Inze D. When plant cells decide to divide.
Trends Plant Sci. 2001;6(8):359-364. doi: 10.1016/s1360-1385(01)02016-7 pmid: 11495789

46. Silveira V, Iochevet Segal Floh E, Handro W, Pedro Guerra M. Effect of plant growth regulators on the cellular growth and levels of intracellular protein, starch and polyamines in embryogenic suspension cultures of Pinus taeda. Plant Cell Tissue Organ Cult. 2004;76(1):53-60. doi: 10.1023/a:1025847515435

47. Machakova I, Zazimalova E. Plant Propagation by Tissue Culture. Netherlands: Springer; 2008.

48. Karadi R, Kavatagimath S, Gaviraj E, Sastry D, Chandrashekhara S, Rajarajeshwari N. Evaluation of Plumbago indica callus for its plumbagin content and antimicrobial activity. J Cell Tissue Res. 2007;7(2):1131.

49. Lisowska $\mathrm{K}$, Wysokinska $\mathrm{H}$. In vitro propagation of Catalpa ovata G. Don. Plant Cell Tissue Organ Cult. 2000;60(3):171-176. doi: 10.1023/1006461520438

50. Qui JA, Castro-Concha LA, García-Sosa K, PeñaRodríguez LM, Miranda-Ham ML. Differential effects of phytotoxic metabolites from Alternaria tagetica on Tagetes erecta cell cultures. J Gen Plant Pathol. 2009;75(5):331-339. doi: 10.1007/s10327-009-0184$\mathrm{y}$

51. Bais HP, Walker TS, McGrew JJ, Vivanco JM. Factors affecting growth of cell suspension cultures of Hypericum perforatum L.(St. John's wort) and production of hypericin. In Vitro Cell Dev Biol Plant. 2002;38(1):58-65. doi: 10.10792FIVP2001253

52. Tabata M. The Mechanism of Shikonin Biosynthesis in Lithospermum Cell Cultures. Plant Tissue Cult Lett. 1996;13(2):117-125.

10.5511/plantbiotechnology1984.13.117

53. Yazaki K, Matsuoka H, Shimomura K, Bechthold A, Sato F. A novel dark-inducible protein, LeDI-2, and its involvement in root-specific secondary metabolism in Lithospermum erythrorhizon. Plant Physiol. 2001;125(4):1831-1841. doi: 10.1104/pp.125.4.1831 pmid: 11299363

54. Arias JP, Zapata K, Rojano B, Arias M. Effect of light wavelength on cell growth, content of phenolic compounds and antioxidant activity in cell suspension cultures of Thevetia peruviana. J Photochem Photobiol B. 2016;163:87-91. doi: 10.1016/j.jphotobiol.2016.08.0 14 pmid: 27541569

55. Hook ILI. Naphthoquinone contents of in vitro cultured plants and cell suspensions of Dionaea muscipula and Drosera species. Plant Cell Tissue Organ Cult. 2001;67(3):281-285. doi: 10.1023/a:1012708819212

56. Nahálka J, Blanárik P, Gemeiner P, Matúsǒvá E, Partlová I. Production of plumbagin by cell suspension cultures of Drosophyllum lusitanicum Link. J Biotechnol. 1996;49(1-3):153-161. doi: 10.1016/01681656(96)01537-4.

57. Panichayupakaranant P, Tewtrakul S. Plumbagin production by root cultures of Plumbago rosea. Ejbiotechnology. 2002;5(3):11-12. doi: 10.2225/vol5issue 3 -fulltext-4. 